\title{
EFEK PEMBERIAN KALIUM DIFORMAT TERHADAP PERFORMA KESEHATAN BENIH IKAN BAWAL AIR TAWAR (Colossoma macropomum)
}

\author{
Ibnu Bangkit Bioshina Suryadi, Kevin Aditya, Ayi Yustiati, dan Iskandar \\ Program Studi Perikanan, Fakultas Perikanan dan Ilmu Kelautan, Universitas Padjadjaran \\ Jl. Raya Bandung-Sumedang KM. 21 Jatinangor, Sumedang, Indonesia \\ E-mail: ibnu.bangkit@unpad.ac.id
}

\begin{abstract}
ABSTRAK
Kalium diformat adalah bahan tambahan pakan berupa molekul asam format garam ganda yang dapat menurunkan $\mathrm{pH}$ dan menghambat bakteri patogen dalam saluran pencernaan. Riset ini bertujuan untuk menentukan dosis kalium diformat (KDF) yang paling efektif dalam pakan untuk meningkatkan performa kesehatan ikan bawal air tawar (Colossoma macropomum). Riset ini menggunakan Rancangan Acak Lengkap (RAL) dengan 4 perlakuan dan 4 ulangan. Perlakuan yang digunakan adalah penambahan KDF pada pakan komersil $(0 \%, 0,1 \%, 0,3 \%$ dan 0,5\%). Setelah 35 hari pemberian KDF, ikan diuji tantang menggunakan Aeromonas hydrophila dengan kepadatan $10^{8} \mathrm{cfu} / \mathrm{ml}$ secara intraperitonial, kemudian diamati selama 14 hari. Parameter yang diamati adalah kelangsungan hidup, jumlah sel darah putih, jumlah sel darah merah, respon terhadap pakan, respon terhadap kejutan dan gejala klinis makroskopis. Hasil riset menunjukkan bahwa jumlah leukosit seluruh perlakuan meningkat sampai hari ke-7 dikarenakan adanya infeksi, kemudian jumlah leukosit menurun kembali pada hari ke-10 menuju kondisi normal. Jumlah eritrosit seluruh perlakuan menurun sampai hari ke-10, hal ini disebabkan oleh adanya aktivitas hemolitik dari A. hydrophila dan kembali meningkat menuju kondisi normal pada hari ke-14. Gejala klinis makroskopis seluruh perlakuan cenderung seragam yaitu sisik mengelupas, bercak merah, perut membengkak dan sirip geripis. Dapat disimpulkan bahwa perlakuan KDF 0,3\% merupakan perlakuan terbaik karena dapat meningkatkan jumlah sel darah putih tertinggi yaitu dari $6,8 \times 10^{4} \mathrm{sel} / \mathrm{mm}^{3}$ menjadi $7,56 \times 10^{4} \mathrm{sel} / \mathrm{mm}^{3}$ selama pemberian 35 hari, serta memiliki nilai kelangsungan hidup tertinggi setelah uji tantang yaitu sebesar 55\%, tidak menimbulkan gejala sirip geripis, serta memiliki respon pakan dan respon terhadap kejutan yang lebih baik daripada perlakuan lainnya.
\end{abstract}

Kata kunci: Ikan Bawal; KDF; A. hydrophila; Kelangsungan Hidup; Performa Kesehatan.

\section{THE EFFECT OF POTASSIUM DIFORMATE AS FEED ADDITIVE ON HEALTH PERFORMANCE OF FRESHWATER POMFRET FINGERLINGS (Colossoma macropomum)}

\begin{abstract}
Potassium diformate is a feed additive in the form of double salt formic acid that can reduced $\mathrm{pH}$ and inhibit pathogenic bacteria in the digestive tract. This study aims to determine the most effective dose of potassium diformate (KDF) as feed additive to enhance health performance of freshwater pomfret (Colossoma macropomum). This research used Completely Randomized Design (CRD) with 4 treatments and 4 replications. The treatments used are the addition of potassium diformate $0 \%, 0.1 \%$, $0.3 \%$ and $0.5 \%$ on commercial feed. After 35 days diets with potassium diformate, the freshwater pomfret fingerlings were challenged by Aeromonas hydrophila with a density of $10^{8} \mathrm{CFU} / \mathrm{ml}$ intraperitonially then observed for 14 days. Observed parameters are survival rate, total leucocyte count, total erythrocyte count, feed responses, shock responses and gross clinical symptoms. The results showed that total leukocyte count is increased until day- $7^{\text {th }}$ due to the infection and tends to decrease on day- $10^{\text {th }}$ towards normal condition. Total erythrocyte count of all treatments until day- $10^{\text {th }}$ are decreased due to hemolytic activity of $A$. hydrophila and increasing to normal conditions on day- $14^{\text {th }}$. Gross clinical symptoms after the challenged test are similar such as ulceration, hemorrhagic, dropsy and fin rot. It can be concluded that the $0.3 \%$ KDF addition is the best treatment because it can increase the highest white blood cell count, from $6.8 \times 10^{4}$ cells $/ \mathrm{mm}^{3}$ to $7.56 \times 10^{4}$ cells $/ \mathrm{mm}^{3}$ during 35 days of administration, and has the highest survival rate of 55\% after challenged, did not show fin rot symptoms, and had better feed response and shock response than other treatments.
\end{abstract}

Keywords: Colossoma macropomum; Potassium Diformate; A. hydrophila; Survival Rate; Health Performance.

\section{PENDAHULUAN}

Jenis ikan bawal air tawar (Colossoma macropomum) merupakan ikan budidaya yang terhitung baru diperkenalkan di industri perikanan Indonesia, dengan jumlah konsumsi semakin hari semakin meningkat (Arie, 2009). Penyakit ikan akan muncul seiring dengan intensifikasi budidaya yang dilakukan para pembudidaya ikan untuk memenuhi kebutuhan pasar yang tinggi. Timbulnya penyakit pada ikan yang umumnya terjadi, disebabkan adanya interaksi antara ikan, patogen dan lingkungan (Khasani, 2006). Hal ini merupakan salah satu masalah serius yang dihadapi oleh para pembudidaya karena berpotensi menimbulkan kerugian yang sangat besar. Kerugian yang terjadi dapat berupa peningkatan jumlah kematian ikan. Selain itu, serangan penyakit dapat menyebabkan penurunan kualitas ikan sehingga secara ekonomis berakibat pada penurunan harga jual (Mariyono \& Sundana, 2002).

Bakteri Aeromonas hydrophila adalah jenis bakteri yang bersifat patogen dan dapat menyebabkan penyakit sistemik serta mengakibatkan kematian secara masal. Bakteri patogen pada ikan dapat bersifat sebagai infeksi primer atau sekunder. Penyakit akibat infeksi bakteria di Indonesia ternyata dapat mengakibatkan kematian sekitar 50-100\% (Wiyanto, 2010). Menurut Rahmaningsih (2012) dan Roberts (2001) A. hydrophila termasuk patogen oportunistik yang hampir selalu ada di dalam air dan menimbulkan 
penyakit apabila ikan dalam kondisi tidak optimal. Serangan bakteri tersebut dapat mengakibatkan gejala seperti penyakit hemoragi septisemia atau Motile Aeromonas Septicemia (MAS) yang mempunyai ciri antara lain seperti luka di permukaan tubuh, luka pada insang, bercak merah, penumpukan nanah, exophthalmia dan perut membengkak (Austin \& Austin, 2007).

Penggunaan antibiotik untuk pengobatan penyakit MAS umum dilakukan oleh pembudidaya, namun hal ini memiliki batasan penggunaan antibiotic growth promotor (AGP). Hal tersebut terjadi karena antibiotik dapat menyebabkan agen penyakit menjadi resisten dan juga semakin kuat. Oleh karena itu, dibutuhkan alternatif yang ditujukan untuk mengganti AGP yang baik dan tidak menimbulkan efek samping seperti asam organik. Beberapa asam organik yang dapat membantu proses penyerapan di dalam saluran pencernaan adalah asam asam format dan kalium diformat (KDF) (Yustiati et al., 2019c).

KDF adalah molekul asam format garam ganda feed additive yang dapat menurunkan $\mathrm{pH}$ dan menghambat bakteri patogen dalam saluran pencernaan. Keuntungan KDF untuk ikan dan udang yaitu membuat kondisi yang tidak menguntungkan bagi bakteri patogen, mendukung pencernaan protein dan mineral serta meningkatkan kinerja pertumbuhan. Selanjutnya keuntungan bagi pakan sendiri yaitu melindungi bahan baku dan pakan olahan dari degradasi bakteri (Arreza, 2017). KDF dapat diberikan dengan dosis yang lebih kecil dibandingkan dengan produk acidifier lainnya. Hal tersebut dikarenakan KDF memiliki struktur diformat (double salt) (Sutisna, 2017).

$\mathrm{KDF}$ terbukti dapat meningkatkan kelangsungan hidup ikan nila (Zhou et al., 2009; Yustiati et al., 2019a) dan pertumbuhan yang lebih baik (Abu-Elala \& Ragaa, 2015), serta meningkatkan resistensi terhadap serangan bakteri A. hydrophila pada ikan patin (Yustiati et al., 2019b), ikan lele (Yustiati et al., 2019c), ikan koki (Yustiati et al., 2020a), dan ikan gurami (Yustiati et al., 2020b). Diharapkan KDF dapat diaplikasikan sebagai bahan tambahan pakan untuk pembudidaya bawal air tawar karena dapat meningkatkan pertumbuhan dan sistem pertahanan tubuh.

\section{METODE}

Penelitian ini dilaksanan di Laboratorium Akuakultur Gedung 4 Fakultas Perikanan dan Ilmu Kelautan Universitas Padjadjaran pada bulan Juni hingga bulan November 2019. Penelitian ini menggunakan metode Rancangan Acak Lengkap (RAL) dengan empat perlakuan dan empat ulangan. Perlakuan yang digunakan adalah perlakuan A (pakan komersil tanpa penambahan kalium diformat), perlakuan B (penambahan kalium diformat $0,1 \%$ pada pakan komersil), perlakuan $\mathrm{C}$ (penambahan kalium diformat $0,3 \%$ pada pakan komersil) dan perlakuan $\mathrm{D}$ (penambahan kalium diformat $0,5 \%$ pada pakan komersil).

\section{Persiapan Penelitian}

Jumlah akuarium yang digunakan adalah 16 buah dengan ukuran $39,8 \times 25,4 \times 28 \mathrm{~cm}^{3}$. Akuarium disterilisasi menggunakan klorin $30 \mathrm{ppm}$ dan diberi aerasi kuat selama 24 jam untuk membasmi mikroba yang tidak diinginkan, kemudian dibilas menggunakan air bersih, lalu diisi air sebanyak 15 liter sebagai media hidup ikan. Kualitas air dijaga sesuai standar menurut Taufiq et al. (2016). Pakan komersil dan KDF dipersiapkan terlebih dahulu, setelah itu pakan komersil ditimbang sebanyak 100 gram untuk setiap perlakuan. KDF ditimbang sesuai perlakuan yaitu $0,1 \% \quad 0,3 \%$ dan $0,5 \%$. KDF dicampurkan kedalam pakan dengan cara penyemprotan, setelah sebelumnya dilarutkan dalam air bersih sebanyak $10 \%$ dari bobot pakan, kemudian dikering-anginkan (Yustiati et al., 2019a; 2019b; 2019c; 2020a; 2020b). Pakan kemudian dikemas menggunakan plastik zipper untuk tiap perlakuan sesuai dengan feeding rate yaitu sebesar 3\% dari biomassa ikan.

\section{Pemeliharaan Ikan}

Ikan bawal air tawar yang digunakan berasal dari Bekasi, Jawa Barat, dengan ukuran 6-7 cm sebanyak 300 ekor. Kepadatan yang digunakan adalah 10 ekor per akuarium. Pakan komersil yang digunakan adalah pakan komersil dengan kandungan protein 39$41 \%$. Frekuensi pemberian pakan KDF sebanyak tiga kali sehari yaitu pada pukul 08.00, 12.00 dan 16.00 WIB selama 35 hari. Penyifonan akuarium dilakukan setiap hari sebanyak $10 \%$ sebelum pemberian pakan awal dan pergantian air dilakukan setiap tujuh hari.

\section{Kultur Bakteri Aeromonas hydrophila}

Bakteri A. hydrophila didapatkan dari Laboratorium Mikrobiologi dan Bioteknologi, FPIK Unpad. Media natrium agar/NA (MERCK, USA) ditimbang sebanyak 1,28 gram. Media dilarutkan dengan aquades sebanyak $100 \mathrm{ml}$ dan dipanaskan hingga homogen menggunakan hot plate. Sterilisasi alat dan media dengan menggunakan autoklaf hingga suhu $121^{\circ} \mathrm{C}$ selama 15 menit pada tekanan 1 atm. Pengambilan biakan bakteri $A$. hydrophila pada media NA di laminar flow. Bakteri A. hydrophila yang sudah diinokulasi diambil menggunakan jarum ose yang sudah dipanaskan dengan bunsen dan alkohol. Jarum ose berisi $A$. hydrophila digoreskan secara merata ke dalam media natrium agar $15 \mathrm{ml}$. Media yang telah digores diinkubasi pada inkubator dengan suhu $37^{\circ} \mathrm{C}$ selama 24 jam. Hasil penggoresan kemudian dibandingkan dengan koloni inokulan awal, untuk memastikan tidak terjadi kontaminasi.

\section{Uji Tantang dengan Aeromonas hydrophila}

Ikan diuji tantang oleh bakteri $A$. hydrophila setelah diberikan pakan KDF selama 35 hari, kemudian diamati selama 14 hari. Infeksi bakteri $A$. hydrophila terhadap ikan bawal dilakukan dengan metode penyuntikan intraperitonial dengan kepadatan $10^{8} \mathrm{cfu} / \mathrm{ml}$. Pengamatan sel darah putih dan sel darah merah dilakukan pada hari ke-3, hari ke-7, hari ke-10 
dan hari ke-14. Sedangkan pengamatan gejala klinis makroskopis dan kelangsungan hidup dilakukan setiap hari.

\section{Parameter Pengamatan}

Parameter pengamatan yang dilakukan pada riset ini yaitu kelangsungan hidup, jumlah sel darah putih, jumlah sel darah merah, gejala klinis makroskopis, respon pakan dan respon terhadap kejutan. Data kelangsungan hidup, sel darah putih dan sel darah merah dianalisis dengan menggunakan uji-F $(\mathrm{p}<0,05)$, sedangkan data respon pakan, respon terhadap kejutan dan gejala klinis makroskopis dianalisis secara deskriptif.

\section{Kelangsungan Hidup (Survival Rate/SR)}

Rumus yang digunakan untuk mengetahui persentase kelangsungan hidup ikan uji menurut Effendie (1997) :

$$
\mathrm{SR}=\frac{\mathrm{Nt}}{\mathrm{No}} \mathrm{x} 100 \%
$$

Keterangan :

$$
\begin{array}{ll}
\mathrm{SR} & =\text { Kelangsungan Hidup }(\%) \\
\mathrm{Nt} & =\text { Jumlah ikan akhir pemeliharaan } \\
\mathrm{No} & =\text { Jumlah ikan awal pemeliharaan }
\end{array}
$$

\section{Perhitungan Sel Darah Merah (Eritrosit)}

Pengambilan darah dilakukan pada pangkal ekor ikan yang kemudian dimasukkan kedalam tabung Eppendorf yang telah diberi antikoagulan. Kemudian darah diambil menggunakan pipet thomma hingga skala 0,5 yang ditambah dengan larutan hayem sampai skala 101. Cairan darah yang sudah merata, dapat ditetesi pada ruang kamar haemocytometer dengan perbesaran lensa okuler 10x dan lensa objektif 40x pada mikroskop. Menurut Nabib \& Pasaribu (1989), rumus perhitungan jumlah sel darah merah $\left(\mathrm{sel} / \mathrm{mm}^{3}\right)$ adalah sebagai berikut :

$$
\mathrm{SDM}=\frac{\text { Jumlah sel darah terhitung }}{\mathrm{V} \text { X FP }}
$$

Keterangan:

$$
\begin{array}{ll}
\mathrm{SDM}= & \text { Jumlah sel darah merah } \\
\mathrm{V} & =\text { Volume kotak haemocytometer yang } \\
& \quad \text { diamati } \\
\mathrm{FP} & =\text { Faktor pengenceran }
\end{array}
$$

\section{Perhitungan Sel Darah Putih (Leukosit)}

Pengambilan darah didapat dari pangkal ekor ikan yang kemudian dimasukkan kedalam tabung Eppendorf yang telah diberi antikoagulan, kemudiansampel darah diambil dengan menggunakan pipet thomma sebatas skala 0,5 dan ditambah larutan Turk sampai skala 11. Cairan darah yang sudah homogen, dapat ditetesi pada ruang kamar haemocytometer dan ditutupi menggunakan cover glass. Perhitungan sel darah dilakukan dibawah mikroskop dengan perbesaran lensa okuler 10x dan lensa objektif 40x. Menurut Nabib \& Pasaribu (1989), rumus perhitungan jumlah sel darah putih $\left(\mathrm{sel} / \mathrm{mm}^{3}\right)$ adalah sebagai berikut:

$$
\text { SDP }=\frac{\text { Jumlah sel darah terhitung }}{\text { V X FP }}
$$

Keterangan:

$$
\begin{array}{ll}
\mathrm{SDP} & =\text { Jumlah sel darah putih } \\
\mathrm{V} & =\text { Volume kotak haemocytometer yang } \\
& \text { diamati } \\
\mathrm{FP} & =\text { Faktor pengenceran }
\end{array}
$$

\section{Gejala Klinis Makroskopis Ikan}

Pengamatan gejala klinis makroskopis meliputi perubahan morfologi dengan melihat kerusakan dipermukaan tubuh berupa kerusakan permukaan tubuh dan organ bagian luar (sisik, perut dan sirip) serta perubahan warna kulit ikan.

\section{Respon Pakan dan Respon Terhadap Kejutan}

Pengamatan respon pakan dilakukan dengan mengamati ikan uji setelah diberi pakan dalam waktu 5 menit. Apabila ikan langsung merespon pakan maka diberi tanda $(+++)$, merespon pakan $\leq 5$ menit diberi tanda (++) dan tidak merespon diberi tanda (-). Respon terhadap kejutan dilakukan dengan cara mengetuk akuarium, jika ikan langsung bergerak lincah maka diberi tanda $(+++)$, ikan bergerak dengan pelan diberi tanda (++) dan tanpa respon diberi tanda (-).

\section{Analisis Data}

Data kelangsungan hidup, sel darah merah dan sel darah putih dianalisis dengan menggunakan uji-F $(\mathrm{p}<0,05)$. Apabila terdapat perbedaan yang nyata, maka pengujian dilanjutkan dengan uji jarak berganda Duncan (Steel \& Torrie 1993). Analisis gejala klinis makroskopis, respon pakan dan respon terhadap kejutan dilakukan secara deskriptif.

\section{HASIL DAN PEMBAHASAN}

\section{Kelangsungan Hidup}

Kelangsungan hidup pasca uji tantang $A$. hydrophila bervariasi pada setiap perlakuan. Tingkat kelangsungan hidup tertinggi terdapat pada perlakuan $\mathrm{C}$ yaitu sebesar $55 \%$, selanjutnya perlakuan D sebesar $38 \%$, perlakuan A sebesar $28 \%$ dan perlakuan B dengan nilai 23\% (Gambar 1). Hasil tersebut (kecuali perlakuan C) sesuai dengan pernyataan Rosidah et al. (2019b) pada budidaya ikan, bakteri A. hydrophila dapat menyebabkan tingkat kematian yang lebih tinggi, yaitu sekitar $80-100 \%$ yang dapat terjadi dalam kurun waktu 7-14 hari.

Pemberian kalium diformat dengan dosis yang tidak optimal (terlalu sedikit atau terlalu banyak) pada ikan bawal air tawar tidak akan meningkatkan ketahanan tubuh, hal ini dapat dilihat dari tidak adanya perbedaan yang nyata antara perlakuan A (tanpa penambahan KDF) dengan perlakuan $\mathrm{B}(0,1 \% \mathrm{KDF})$. Berikut pada Gambar 1 disajikan data kelangsungan hidup bawal air tawar setelah diuji tantang selama 14 hari oleh A. hydrophila. 


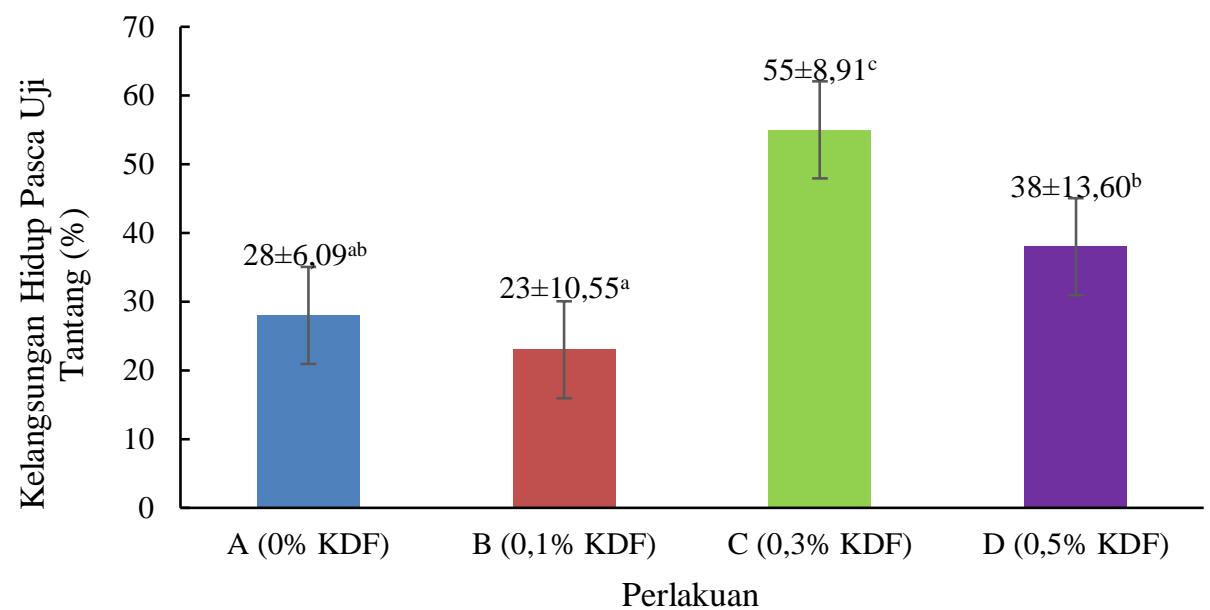

Gambar 1 Grafik kelangsungan hidup bawal air tawar pasca uji tantang.

Kelangsungan hidup tertinggi terdapat pada perlakuan $\mathrm{C}(0,3 \% \mathrm{KDF})$ dan berbeda nyata dengan perlakuan lainnya, hal ini mengindikasikan bahwa perlakuan tersebut merupakan dosis terbaik karena dapat meningkatkan kekebalan tubuh bawal air tawar terhadap serangan A. hydrophila. Hasil ini sesuai dengan Zhou et al. (2009) yang menyatakan bahwa dosis optimal untuk kelangsungan hidup dan pertumbuhan pada ikan nila hibrid adalah $0,3 \%$. Didukung pula oleh hasil riset Ramli et al. (2005) yang menemukan bahwa dosis $0,3 \%$ KDF memberikan nilai kelangsungan hidup dan pertumbuhan paling optimal pada ikan nila yang diuji tantang oleh bakteri Vibrio anguillarum.

Menurut Lückstädt et al. (2008) mekanisme kerja KDF dalam usus dan lambung adalah dengan cara mengurangi nilai $\mathrm{pH}$, melalui pengiriman $\mathrm{H}+$ serta menghambat pertumbuhan bakteri gram negatif melalui disosiasi asam dan produksi anion didalam sel bakteri, pada keadaan $\mathrm{pH}$ lambung dan usus rendah atau dalam kondisi asam $(\mathrm{pH}<5)$, maka akan menurunkan pertumbuhan bakteri Gram negatif seperti Escherichia coli dan Salmonella. Selain itu, berat molekul asam yang rendah dapat memecah membran sel bakteri gram negatif, sehingga molekul sitoplasma akan pecah. Nilai $\mathrm{pH}$ yang rendah ini mengubah metabolisme sel dan aktivitas enzim, sehingga menghambat pertumbuhan mikroba intralumenal, terutama yang patogen. Beberapa riset telah menunjukkan pengurangan jumlah bakteri pada lambung dan usus, namun Lactobacillus (bakteri asam laktat / BAL) yang bersifat menguntungkan bagi inang tidak terpengaruh bahkan meningkat jumlahnya. Bakteri asam laktat dapat hidup pada kondisi lingkungan yang asam dan membantu penyerapan pakan. Dengan jumlah BAL yang meningkat pada saluran pencernaan, maka mikroba patogen dapat berkurang karena terjadi persaingan. Hal tersebut mengakibatkan peningkatan performa pertumbuhan dan daya tahan tubuh ikan.

Semakin tinggi dosis KDF yang diberikan tidak selalu akan meningkatkan kelangsungan hidup benih ikan bawal air tawar, dikarenakan KDF berbentuk garam asam organik dan apabila penggunannya terlalu banyak akan menyebabkan gangguan osmoregulasi. Menurut Argenzio \& Eisemann (1996), penggunaan asam organik dalam dosis yang berlebihan dari nilai yang telah terbukti optimum, dapat merusak mukosa perut dan duodenum.

\section{Sel Darah Putih}

Pengamatan sel darah putih dilakukan untuk menentukan kondisi kesehatan ikan dengan mengamati adanya kenaikan atau penurunan jumlahnya (Rosidah et al., 2019a). Hasil pengamatan sel darah putih benih bawal air tawar sebelum pemberian KDF (sebelum riset) yaitu 6,8 x $10^{4}$ $\mathrm{sel} / \mathrm{mm}^{3}$ (Gambar 2). Nilai tersebut masih mendekati kisaran normal, menurut Hasibuan (2017) yaitu rentang nilai leukosit normal pada bawal air tawar berukuran $13-16 \mathrm{~cm}$ adalah $1,27 \times 10^{5}-1,37 \times 10^{5}$ $\mathrm{sel} / \mathrm{mm}^{3}$. Perbedaan tersebut dikarenakan ukuran ikan yang digunakan pada riset ini berukuran lebih kecil yaitu 6-7 cm. Setelah pemberian KDF selama 35 hari dengan dosis yang berbeda, seluruh perlakuan jumlah sel darah putih meningkat dengan kisaran 7,56-8,68 x $10^{4} \mathrm{sel} / \mathrm{mm}^{3}$. Perlakuan $\mathrm{C}$ mengalami peningkatan paling tinggi dengan nilai $8,68 \times 10^{4} \mathrm{sel} / \mathrm{mm}^{3}$ dan yang paling rendah yaitu pada perlakuan A kontrol dengan nilai $7,56 \times 10^{4} \mathrm{sel} / \mathrm{mm}^{3}$.

Jumlah sel darah putih bervariasi pada setiap perlakuan, semakin tinggi dosis KDF yang diberikan tidak selalu akan meningkatkan sel darah putih. Hal tersebut dikarenakan KDF merupakan garam organik, jika jumlahnya terlalu banyak akan menyebabkan energi didalam tubuh ikan akan digunakan untuk menyeimbangkan sistem osmoregulasi (Lantu, 2010; Yustiati et al., 2019a). Menurut hasil uji F (p<0,05) peningkatan jumlah leukosit setelah pemeliharaan 35 hari memiliki perbedaan yang nyata, perlakuan $\mathrm{C}$ merupakan dosis paling baik dengan nilai yang paling tinggi.

Peningkatan sel darah putih ini dipengaruhi oleh KDF, karena KDF merupakan asam organik yang dibuat dengan teknologi garam ganda yang berperan 
sebagai imunostimulan (Lückstädt \& Kühlmann, 2016). Hal ini menurut Da Silva et al. (2013) dikarenakan asam organik dan garam-garam pada kalium diformat juga dapat berkontribusi dalam generasi ATP untuk menghasilkan energi dalam metabolisme tubuh. Sehingga terdapat kelebihan energi untuk sistem pertahanan tubuh ikan.

Setelah pemeliharaan dengan KDF selama 35 hari, benih ikan bawal selanjutnya diuji tantang oleh A. hydrophila. Pasca uji tantang hari ke-3, seluruh sel darah putih meningkat pada setiap perlakuan dosis pemberian KDF. Nilai sel darah putih paling tinggi yaitu pada perlakuan B nilai $10,42 \times 10^{4} \mathrm{sel} / \mathrm{mm}^{3}$ sementara yang paling rendah yaitu pada perlakuan $\mathrm{C}$ dengan nilai $10,94 \times 10^{4} \mathrm{sel} / \mathrm{mm}^{3}$.

Peningkatan jumlah rata-rata sel darah putih berlangsung hingga pada hari ke-7 setelah penyuntikan bakteri. Meningkatnya nilai leukosit dengan melebihi batas normal menandakan bahwa infeksi masih terjadi didalam tubuh ikan (Setiawati et al., 2007; Hastuti \& Karoror, 2007). Menurut Moyle \& Cech (2004), leukosit akan lebih banyak diproduksi oleh ikan yang sakit untuk memfagosit bakteri dan mensintesa antibodi. Nilai peningkatan sel darah putih pada perlakuan $\mathrm{C}$ menandakan adanya pengaruh $\mathrm{KDF}$ untuk meningkatkan sistem pertahanan tubuh yang optimal, hal ini ditandakan dengan peningkatan sel darah putih yang tidak terlalu tinggi dan nilai kelangsungan hidup tertinggi.
Setelah hari ke-10 jumlah sel darah putih ikan bawal air tawar mengalami penurunan dan merupakan awal fase penyembuhan pada seluruh perlakuan. Menurunnya semua nilai leukosit pada seluruh perlakuan menandakan bahwa serangan bakteri $A$. hydrophila mulai menurun, ikan sudah memasuki fase penyembuhan. Hasil ini sesuai dengan riset Yustiati et al. (2019c), dimana sel darah putih ikan lele sangkuriang yang diuji tantang oleh A. hydrophila mengalami penurunan pada hari ke-10.

Perlakuan C $(0,3 \%$ KDF $)$ merupakan perlakuan terbaik dengan peningkatan leukosit paling tinggi setelah diberi KDF selama 35 hari, mengalami peningkatan leukosit terendah pada pasca uji tantang hari ke-3 dan mengalami perubahan paling tinggi pada penyembuhan pasca uji tantang hari ke-10. Hal ini sesuai dengan riset serupa yang dilakukan Yustiati et al. (2020a; 2020b) pada ikan mas koki dan gurami.

\section{Sel Darah Merah}

Pengamatan sel darah merah pada riset ini bertujuan untuk mengetahui pengaruh penginfeksian bakteri A. hydrophila terhadap profil darah merah benih bawal air tawar yang telah diberi KDF dan tidak diberi KDF selama perlakuan, karena bakteri tersebut memiliki enzim hemolisin yang dapat melisiskan sel darah merah (Nzeako et al., 1991). Hasil perhitungan jumlah rata-rata sel darah merah dapat dilihat pada Gambar 3.

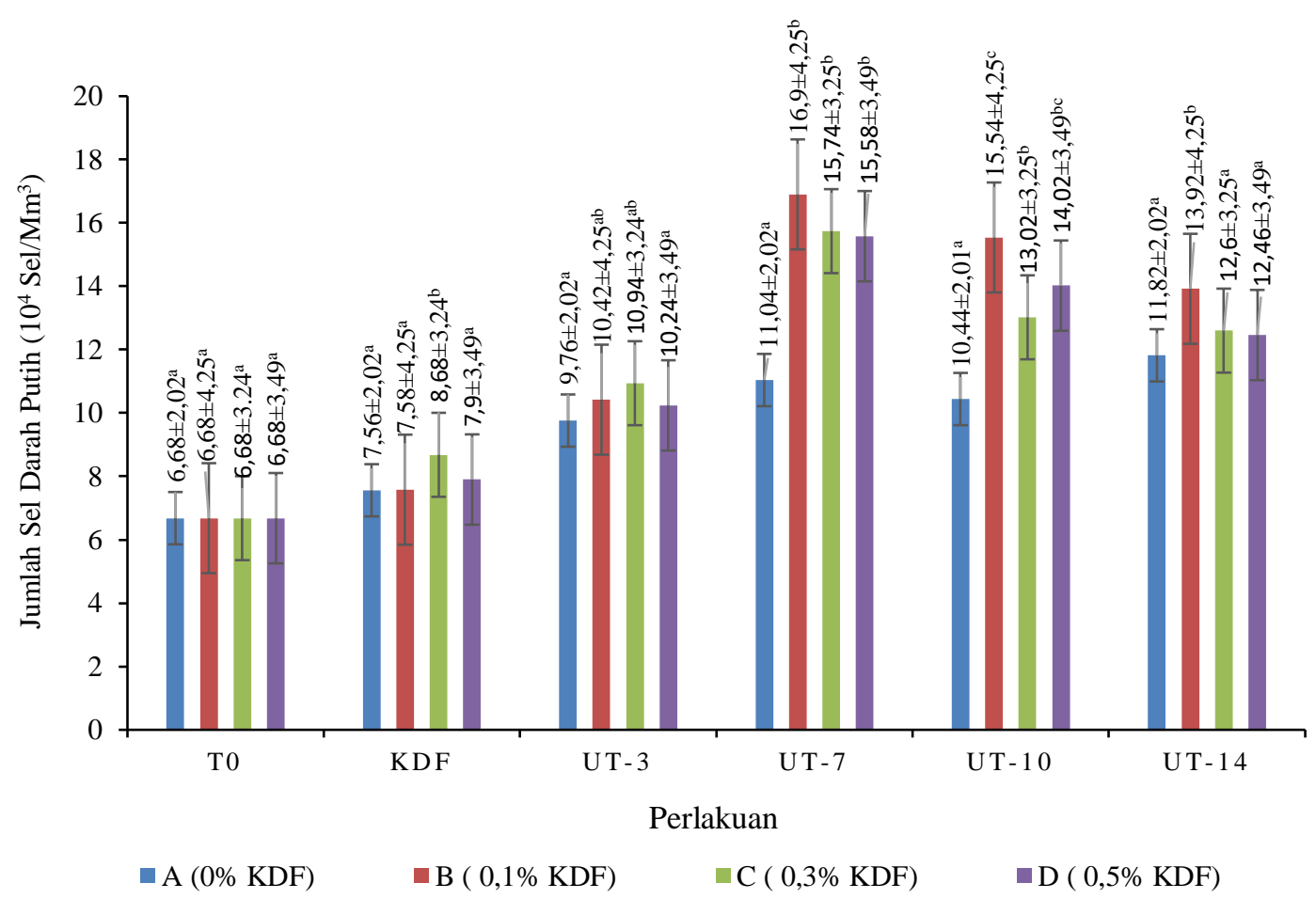

Gambar 2 Jumlah sel darah putih ikan bawal air tawar.

Keterangan

T0 : sebelum perlakuan

$\mathrm{KDF}$ : setelah perlakuan pemberian $\mathrm{KDF}$ selama 35 hari

UT-3 : uji tantang hari ke-3
UT-7 : uji tantang hari ke-7

UT-10 : uji tantang hari ke-10

UT-14 : uji tantang hari ke-14 


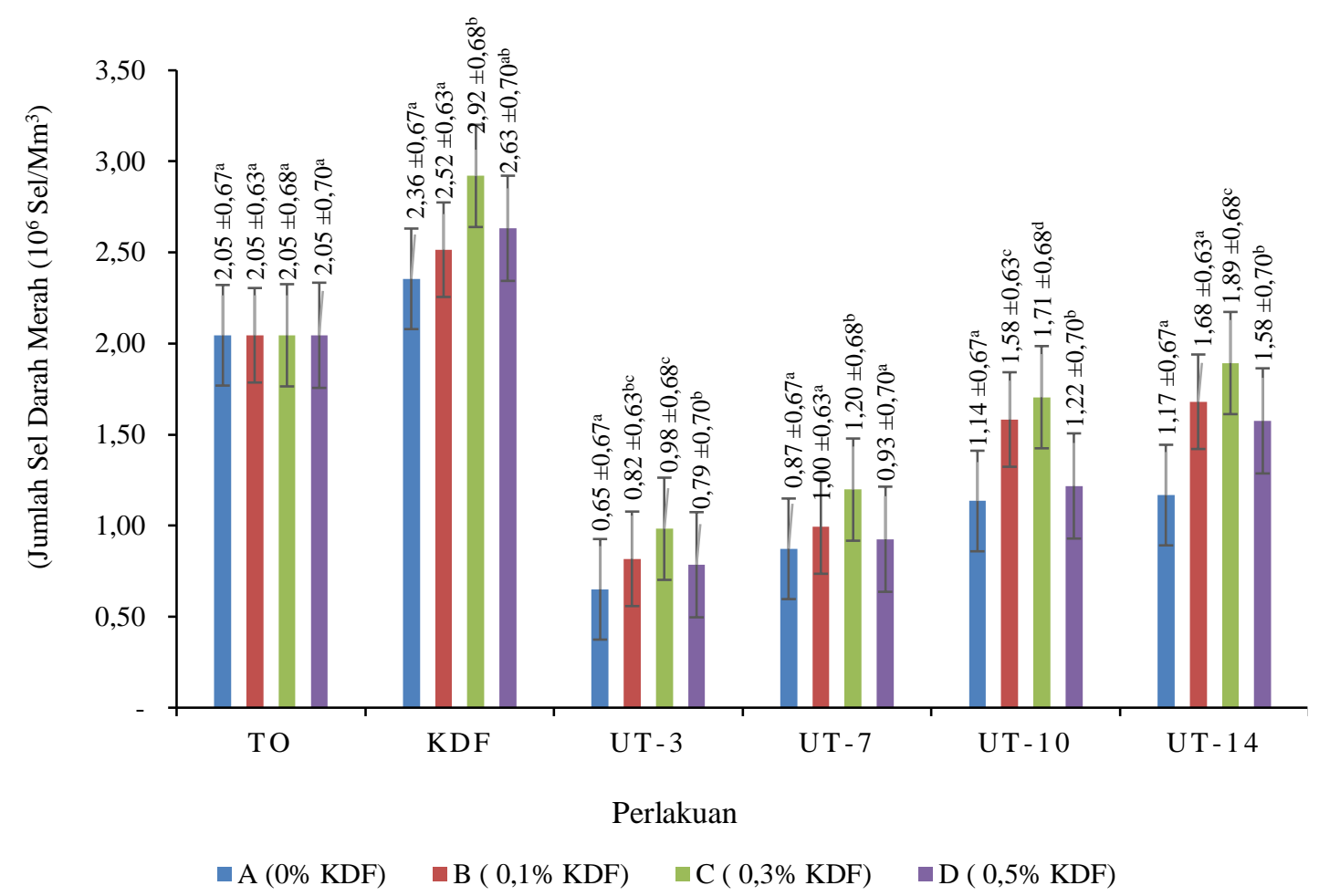

Gambar 3 Jumlah sel darah merah ikan bawal air tawar.

Keterangan

T0 : sebelum perlakuan

$\mathrm{KDF}$ : setelah perlakuan pemberian KDF selama 35 hari

UT-3 : uji tantang hari ke-3

Berdasarkan Gambar 3 nilai sel darah merah ikan bawal sebelum pemberian KDF yaitu 2,05 x10 $\mathrm{sel} / \mathrm{mm}^{3}$. Ikan bawal normal memiliki jumlah sel darah merah dengan kisaran 2,21 - 2,37 x10 $\mathrm{sel} / \mathrm{mm}^{3}$ (Hasibuan, 2017). Setelah pemeliharaan dengan KDF selama 35 hari, nilai rata-rata jumlah sel darah merah meningkat pada seluruh perlakuan. Jumlah paling tinggi yaitu pada perlakuan $\mathrm{C}$ dengan nilai $2,92 \times 10^{6}$ $\mathrm{sel} / \mathrm{mm}^{3}$ dan yang paling rendah yaitu pada perlakuan A dengan nilai $2,36 \times 10^{6} \mathrm{sel} / \mathrm{mm}^{3}$. Peningkatan jumlah sel darah merah pada perlakuan tanpa pemberian $\mathrm{KDF}$ (A) dikarenakan adanya pemberian nutrisi dari pakan komersil dan bertambahnya umur, sesuai dengan pernyataan Yanto et al. (2015), faktor yang mempengaruhi jumlah sel darah merah ikan antara lain oksigen, lingkungan, nutrisi, umur dan jenis kelamin. Meningkatnya jumlah sel darah merah akan mengakibatkan jumlah hemoglobin juga mengalami peningkatan, sehingga oksigen dapat diikat lebih banyak, dengan oksigen yang cukup akan membuat metabolisme tubuh ikan berjalan baik (Yustiati et al., 2019b).

Setelah pemeliharaan dengan KDF selama 35 hari, ikan bawal diuji tantang oleh A. hydrophila. Hasil uji tantang pada hari ke-3, rata-rata sel darah merah ikan bawal mengalami penurunan pada semua perlakuan. Perlakuan A memiliki rata-rata penurunan tertinggi yaitu $6,5 \times 10^{6} \mathrm{sel} / \mathrm{mm}^{3}$ dan perlakuan $\mathrm{C}$

\section{UT-7 : uji tantang hari ke-7 \\ UT-10 : uji tantang hari ke-10 \\ UT-14 : uji tantang hari ke-14}

paling rendah dengan nilai $0,98 \times 10^{6} \mathrm{sel} / \mathrm{mm}^{3}$. Penurunan jumlah sel darah merah merupakan salah satu dampak dari serangan bakteri A. hydrophila (Haditomo et al., 2014; Sukandar et al., 2018) karena menyerang organ pembentuk sel darah merah (sumsum tulang belakang, hati dan limpa) (Salasia et al., 2001). Selain itu, menurut Sukenda et al. (2008) infeksi bakteri $A$. hydrophila mampu melisiskan sel darah merah ikan dengan cara menghasilkan toksin berupa enzim ekstraseluler yang dikenal dengan nama hemolisin.

Pada hari ke-7 jumlah eritrosit pada semua perlakuan kembali meningkat. Perlakuan A memiliki peningkatan paling tinggi yaitu menjadi $0,87 \times 10^{6}$ $\mathrm{sel} / \mathrm{mm}^{3}$ dan perlakuan $\mathrm{D}$ memiliki peningkatan terendah menjadi $0,93 \times 10^{6} \mathrm{sel} / \mathrm{mm}^{3}$. Pada perlakuan $\mathrm{D}$, peningkatan sel darah merah lebih rendah walaupun dengan dosis KDF yang lebih tinggi, hal ini sesuai dengan pernyataan Yustiati et al. (2019c) yang menyatakan bahwa pemberian KDF yang berlebihan dapat membuat gangguan osmoregulasi, sehingga energi dialokasikan untuk membuang kelebihan KDF didalam tubuh. Perlakuan A mengalami perubahan paling tinggi disebabkan sebelumnya sel darah merah pada hari ke-3 memiliki nilai yang sangat rendah. Sementara perlakuan $\mathrm{C}$ memiliki nilai paling tinggi yaitu $1,20 \times 10^{6} \mathrm{sel} / \mathrm{mm}^{3}$. Pada hari ke-10, jumlah sel darah merah pada ikan mengalami peningkatan secara 
pesat hal tersebut menandakan bahwa pada hari ke-10 ikan uji sudah memasuki fase penyembuhan. Peningkatan sel darah merah terjadi karena tubuh ikan memproduksi sel darah merah lebih banyak untuk menggantikan sel darah merah yang mengalami lisis akibat infeksi patogen, proses ini dikenal dengan istilah homeostatis (Hardi et al., 2011).

Perlakuan C $(0,3 \%$ KDF $)$ merupakan perlakuan terbaik dengan peningkatan eritrosit paling tinggi setelah diberi KDF selama 35 hari, mengalami peningkatan eritrosit paling tinggi pada pasca uji tantang hari ke-3 dan memiliki nilai paling tinggi pada awal penyembuhan pasca uji tantang hari ke-7. Hasil ini sesuai dengan penelitian Yustiati et al. (2020a; 2020b) yang menyatakan bahwa dosis 0,3\% KDF meningkatkan jumlah eritrosit ikan mas koki dan gurami pada hari ke-3 dan ke-7 setelah ikan diuji tantang dengan $A$. hydrophila.

\section{Gejala Klinis Makroskopis}

Pengamatan gejala klinis makroskopis meliputi perubahan morfologi dengan melihat kerusakan dipermukaan tubuh organ bagian luar (sisik, perut dan sirip) serta perubahan warna kulit ikan, respon terhadap pakan dan respon gerak. Berikut pada Tabel 1 dapat dilihat kerusakan tubuh benih ikan bawal air tawar selama 14 hari setelah diuji tantang oleh $A$. hydrophila.

Berdasarkan Tabel 1, terjadi kerusakan pada permukaan tubuh pada hari pertama berupa sisik mengelupas dan bercak merah. Menurut Mulia (2007) dan Wahjuningrum (2010) A.hydrophila mengeluarkan senyawa eksotoksin. Senyawa eksotoksin yang dikeluarkan A. hydrophila akan disebarkan ke seluruh tubuh melalui aliran darah sehingga menyebabkan hemolisis dan pecahnya pembuluh darah. Hal tersebut menyebabkan darah keluar dari pembuluhnya sehingga menimbulkan bercak merah pada permukaan tubuh ikan. Kerusakan permukaan tubuh ikan masih terus terjadi pada hari ke-3 hingga hari ke-7. Perut membengkak (dropsy) disebabkan oleh adanya pelepasan Aerolysin Cytotoxic Enterotoxic (ACT-gene) yang dapat menyebabkan kerusakan jaringan (Austin \& Austin, 2016). Dropsy merupakan penyakit yang ditimbulkan akibat adanya organ dalam tubuh ikan yang terkena infeksi oleh endotoksin dari A. hydrophila (Angka, 2001).

Pada hari ke-4 ikan pada perlakuan A (kontrol) terdapat sirip geripis. Hasil tersebut sesuai dengan riset Yuhana et al. (2008). Menurut Angka (2001) rusaknya sirip ikan dikarenakan adanya penyumbatan pembuluh darah dan lendir yang diakibatkan oleh endotoksin (LPS / lipopolisakarida). Sisik mengelupas masih terjadi pada semua perlakuan sampai hari ke14. Sisik mengelupas terjadi akibat adanya kerusakan sel akut.

Kerusakan pada bagian sisik diduga timbul karena terjadinya nekrosis, yaitu kematian sel yang tidak terkontrol, sehingga menyebabkan suatu sel menjadi rusak. Price \& Wilson (2006), menyatakan bahwa nekrosis dapat terjadi akibat gangguan metabolisme, defisiensi pakan, aktivitas mikroorganisme dan bahan beracun. Menurut Rehulka (2002) bercak merah atau lesi termasuk peradangan granulositik yang menyebabkan nekrosis, disertai dengan disintegrasi serat otot yang pada akhirnya sisik ikan menjadi terkelupas. Berikut pada Gambar 4 disajikan perubahan bentuk tubuh bawal air tawar yang terinfeksi oleh A. hydrophila.

Tabel 1 Perubahan morfologi bawal air tawar setelah uji tantang.

\begin{tabular}{|c|c|c|c|c|c|c|c|c|c|c|c|c|c|c|}
\hline \multirow{2}{*}{ Perlakuan } & \multicolumn{14}{|c|}{ Hari ke- } \\
\hline & 1 & 2 & 3 & 4 & 5 & 6 & 7 & 8 & 9 & 10 & 11 & 12 & 13 & 14 \\
\hline a1 & $\mathrm{ab}$ & abc & abc & abcd & abcd & Abc & abc & abc & $\mathrm{ab}$ & $\mathrm{ab}$ & $\mathrm{ab}$ & $\mathrm{ab}$ & $\mathrm{ab}$ & $\mathrm{a}$ \\
\hline $\mathrm{a} 2$ & $\mathrm{ab}$ & $a b c$ & $a b c$ & abcd & $\mathrm{abc}$ & $\mathrm{Abc}$ & $\mathrm{ab}$ & $\mathrm{ab}$ & $\mathrm{ab}$ & $\mathrm{ab}$ & $\mathrm{ab}$ & $\mathrm{ab}$ & $\mathrm{ab}$ & $\mathrm{a}$ \\
\hline $\mathrm{a} 3$ & $\mathrm{ab}$ & $\mathrm{abc}$ & $\mathrm{abc}$ & abcd & abcd & $\mathrm{Abc}$ & abc & $\mathrm{abc}$ & $\mathrm{ab}$ & $\mathrm{a}$ & $\mathrm{a}$ & $\mathrm{a}$ & $\mathrm{a}$ & $\mathrm{a}$ \\
\hline $\mathrm{a} 4$ & $\mathrm{ab}$ & $\mathrm{abc}$ & $\mathrm{abc}$ & $\mathrm{abc}$ & abcd & $\mathrm{Abc}$ & abc & $\mathrm{ab}$ & $\mathrm{ab}$ & $\mathrm{a}$ & $\mathrm{a}$ & $\mathrm{a}$ & $\mathrm{a}$ & $\mathrm{a}$ \\
\hline b1 & $\mathrm{ab}$ & abc & abc & abc & abcd & $\mathrm{Abc}$ & abc & $\mathrm{ab}$ & $\mathrm{ab}$ & $\mathrm{a}$ & $\mathrm{a}$ & $\mathrm{a}$ & $\mathrm{a}$ & $\mathrm{a}$ \\
\hline b2 & $\mathrm{ab}$ & $\mathrm{abc}$ & $\mathrm{abc}$ & $\mathrm{abc}$ & abcd & $\mathrm{Abc}$ & abc & $\mathrm{ab}$ & $\mathrm{ab}$ & $\mathrm{a}$ & $\mathrm{a}$ & $\mathrm{a}$ & $\mathrm{a}$ & $\mathrm{a}$ \\
\hline b3 & $\mathrm{ab}$ & $\mathrm{abc}$ & $\mathrm{abc}$ & $\mathrm{abc}$ & abcd & $\mathrm{Abc}$ & abc & $a b$ & $a b$ & $\mathrm{a}$ & $\mathrm{a}$ & $\mathrm{a}$ & $\mathrm{a}$ & $\mathrm{a}$ \\
\hline b4 & $\mathrm{ab}$ & $\mathrm{abc}$ & $\mathrm{abc}$ & $\mathrm{abc}$ & $\mathrm{abc}$ & $\mathrm{Abc}$ & $\mathrm{abc}$ & $\mathrm{ab}$ & $\mathrm{ab}$ & $\mathrm{a}$ & $\mathrm{a}$ & $\mathrm{a}$ & $\mathrm{a}$ & $\mathrm{a}$ \\
\hline $\mathrm{cl}$ & $\mathrm{ab}$ & $\mathrm{abc}$ & $\mathrm{abc}$ & $\mathrm{abc}$ & $a b c$ & $\mathrm{Abc}$ & $a b c$ & $\mathrm{ab}$ & $a b$ & $\mathrm{a}$ & $\mathrm{a}$ & $\mathrm{a}$ & $\mathrm{a}$ & $\mathrm{a}$ \\
\hline $\mathrm{c} 2$ & $\mathrm{ab}$ & $\mathrm{ab}$ & $\mathrm{ab}$ & $a b c$ & abcd & $\mathrm{Abc}$ & $a b c$ & $a b c$ & $\mathrm{ab}$ & $\mathrm{a}$ & $\mathrm{a}$ & $\mathrm{a}$ & $\mathrm{a}$ & $\mathrm{a}$ \\
\hline c3 & $\mathrm{ab}$ & $\mathrm{ab}$ & $\mathrm{ac}$ & $\mathrm{abc}$ & $a b c$ & $\mathrm{Abc}$ & $a b c$ & $\mathrm{ab}$ & $a b$ & $\mathrm{a}$ & $\mathrm{a}$ & $\mathrm{a}$ & $\mathrm{a}$ & $\mathrm{a}$ \\
\hline $\mathrm{c} 4$ & $\mathrm{ab}$ & $\mathrm{ab}$ & $\mathrm{abc}$ & $\mathrm{abc}$ & $a b c$ & $\mathrm{Abc}$ & $a b c$ & $\mathrm{ab}$ & $\mathrm{ab}$ & $\mathrm{a}$ & $\mathrm{a}$ & $\mathrm{a}$ & $\mathrm{a}$ & $\mathrm{a}$ \\
\hline $\mathrm{d} 1$ & $\mathrm{ab}$ & $\mathrm{ab}$ & $\mathrm{abc}$ & $\mathrm{abc}$ & $a b c$ & $\mathrm{Abc}$ & $a b c$ & $\mathrm{ab}$ & $\mathrm{ab}$ & $\mathrm{ab}$ & $\mathrm{a}$ & $\mathrm{a}$ & $\mathrm{a}$ & $\mathrm{a}$ \\
\hline $\mathrm{d} 2$ & $\mathrm{ab}$ & $\mathrm{abc}$ & $a b c$ & $\mathrm{abc}$ & abcd & $\mathrm{Abc}$ & $a b c$ & $a b c$ & $a b$ & $a b$ & $\mathrm{a}$ & $\mathrm{a}$ & $\mathrm{a}$ & $\mathrm{a}$ \\
\hline $\mathrm{d} 3$ & $a b$ & $\mathrm{abc}$ & $a b c$ & $\mathrm{abc}$ & abcd & $\mathrm{Abc}$ & $a b c$ & $a b$ & $a b$ & $a b$ & $\mathrm{a}$ & $\mathrm{a}$ & $\mathrm{a}$ & $\mathrm{a}$ \\
\hline $\mathrm{d} 4$ & $\mathrm{ab}$ & $\mathrm{abc}$ & $a b c$ & $\mathrm{abc}$ & abc & abcd & $a b c$ & $\mathrm{ab}$ & $a b$ & $a b$ & $\mathrm{a}$ & $\mathrm{a}$ & $\mathrm{a}$ & $\mathrm{a}$ \\
\hline
\end{tabular}

Keterangan : (a) Sisik mengelupas, (b) Bercak merah, (c) Perut membengkak, (d) Sirip geripis. 


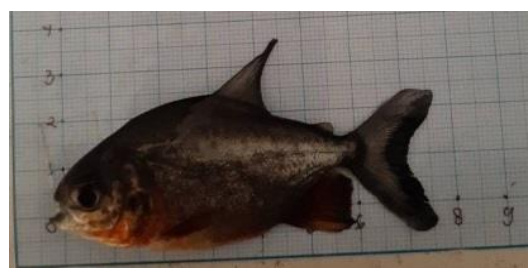

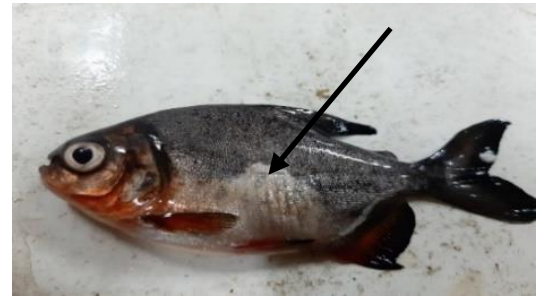

Sisik Mengelupas

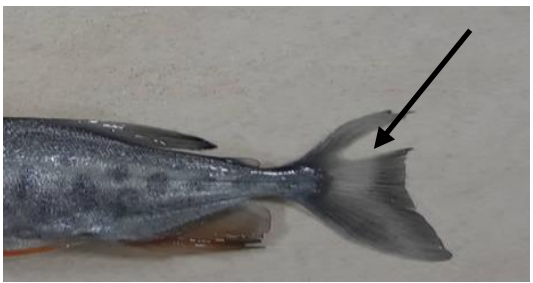

Sirip Geripis

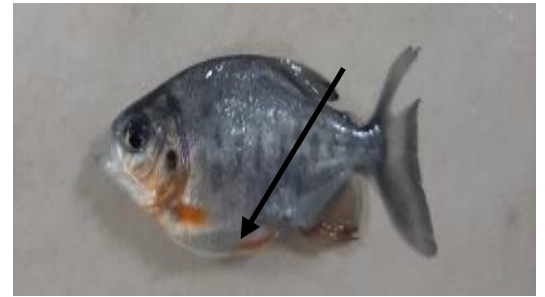

Perut Membengkak

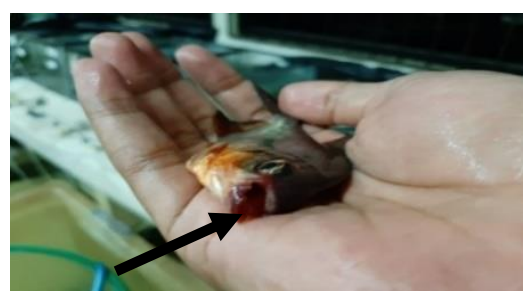

Bercak Merah Pada Mulut

Gambar 4 Kerusakan tubuh pada ikan bawal.

\section{a) Respon Pakan}

Pasca uji tantang hari pertama, semua perlakuan mengalami respon pakan yang sedang, selanjutnya pada hari ke-2 sampai ke-5 hampir semua perlakuan mengalami penurunan respon terhadap pakan, hal tersebut karena mulai pada hari ke-2 $A$. hydrophila sudah mulai menyerang sistem imun ikan secara menyeluruh sampai hari ke-5. Perlakuan A mengalami penurunan respon terhadap pakan pada jangka waktu tersebut. Ikan yang terkena penyakit atau nafsu makannya menurun, maka nilai hematokrit darahnya menjadi tidak normal dan diikuti dengan jumlah eritrosit yang juga rendah (Bastiawan et al.
1995) seperti yang terlihat pada Gambar 3. Menurut Kabata (1985); Cipriano \& Bullock (2001) dan Ali et al. (2014) bakteri A. hydrophila berkembang biak didalam usus yang menyebabkan pendarahan selaput pada usus, sehingga nafsu makan ikan menurun. Muslim et al. (2009) menambahkan bahwa menurunnya respon pakan pada ikan disebabkan karena adanya gangguan metabolisme didalam tubuh, sehingga menyebabkan terjadinya kelainan organ dalam berupa pembengkakan atau peradangan hati, ginjal dan empedu pasca penyuntikan bakteri $A$. hydrophila. Respon pemberian pakan benih ikan bawal air tawar dapat dilihat pada Tabel 2 berikut.

Tabel 2 Respon bawal air tawar terhadap pakan

\begin{tabular}{|c|c|c|c|c|c|c|c|c|c|c|c|c|c|c|}
\hline \multirow{2}{*}{ Perlakuan } & \multicolumn{14}{|c|}{ Hari Ke- } \\
\hline & 1 & 2 & 3 & 4 & 5 & 6 & 7 & 8 & 9 & 10 & 11 & 12 & 13 & 14 \\
\hline A1 & ++ & + & + & + & + & ++ & ++ & ++ & ++ & ++ & ++ & ++ & ++ & ++ \\
\hline A 2 & ++ & + & + & + & + & ++ & ++ & ++ & ++ & ++ & ++ & ++ & ++ & ++ \\
\hline A3 & + & + & + & + & + & ++ & ++ & +++ & +++ & ++ & +++ & +++ & +++ & +++ \\
\hline A4 & ++ & + & + & + & + & ++ & ++ & +++ & +++ & +++ & +++ & +++ & +++ & +++ \\
\hline B1 & ++ & + & + & + & + & ++ & ++ & +++ & +++ & +++ & +++ & +++ & +++ & +++ \\
\hline B2 & ++ & + & + & + & + & ++ & ++ & +++ & +++ & +++ & +++ & +++ & +++ & +++ \\
\hline B3 & ++ & ++ & + & + & + & ++ & ++ & ++ & +++ & +++ & +++ & +++ & +++ & +++ \\
\hline B4 & ++ & + & + & + & + & ++ & ++ & ++ & +++ & +++ & +++ & +++ & +++ & +++ \\
\hline $\mathrm{C} 1$ & ++ & + & + & + & + & + & ++ & ++ & +++ & +++ & +++ & +++ & +++ & +++ \\
\hline $\mathrm{C} 2$ & ++ & ++ & ++ & ++ & ++ & ++ & ++ & +++ & +++ & +++ & +++ & +++ & +++ & +++ \\
\hline C3 & ++ & ++ & + & + & + & ++ & ++ & +++ & +++ & +++ & +++ & +++ & +++ & +++ \\
\hline $\mathrm{C} 4$ & ++ & + & + & + & ++ & ++ & ++ & +++ & +++ & +++ & ++ & +++ & +++ & +++ \\
\hline D1 & + & + & + & + & + & ++ & ++ & +++ & +++ & +++ & +++ & +++ & +++ & +++ \\
\hline D2 & ++ & ++ & + & + & + & ++ & ++ & ++ & +++ & +++ & +++ & +++ & +++ & +++ \\
\hline D3 & ++ & + & + & + & + & ++ & ++ & +++ & +++ & +++ & +++ & +++ & +++ & +++ \\
\hline D4 & ++ & + & + & + & + & ++ & ++ & +++ & +++ & +++ & +++ & +++ & +++ & +++ \\
\hline
\end{tabular}

Keterangan : (+) Respon terhadap pakan rendah, (++) Respon terhadap pakan sedang, (+++) Respon terhadap pakan tinggi. 
Tabel 3. Respon terhadap kejutan

\begin{tabular}{|c|c|c|c|c|c|c|c|c|c|c|c|c|c|c|}
\hline \multirow{2}{*}{ Perlakuan } & \multicolumn{14}{|c|}{ Hari Ke- } \\
\hline & 1 & 2 & 3 & 4 & 5 & 6 & 7 & 8 & 9 & 10 & 11 & 12 & 13 & 14 \\
\hline A1 & + & + & + & + & + & ++ & ++ & ++ & ++ & ++ & ++ & ++ & ++ & ++ \\
\hline A2 & + & + & + & + & + & ++ & ++ & ++ & ++ & ++ & ++ & ++ & ++ & ++ \\
\hline A3 & + & + & + & + & + & ++ & ++ & ++ & ++ & ++ & ++ & ++ & ++ & ++ \\
\hline A4 & + & + & + & + & + & + & ++ & ++ & ++ & ++ & ++ & ++ & ++ & ++ \\
\hline B1 & + & + & + & ++ & ++ & ++ & ++ & ++ & ++ & ++ & ++ & ++ & ++ & ++ \\
\hline B2 & + & + & + & + & + & ++ & ++ & ++ & ++ & ++ & ++ & ++ & ++ & ++ \\
\hline B3 & + & + & + & + & + & ++ & ++ & ++ & ++ & ++ & ++ & ++ & ++ & ++ \\
\hline B4 & + & + & + & + & + & ++ & ++ & ++ & ++ & ++ & ++ & ++ & ++ & ++ \\
\hline $\mathrm{C} 1$ & + & + & + & + & + & ++ & ++ & ++ & ++ & ++ & ++ & ++ & ++ & ++ \\
\hline $\mathrm{C} 2$ & + & + & ++ & ++ & ++ & ++ & ++ & ++ & ++ & ++ & ++ & ++ & ++ & ++ \\
\hline C3 & + & + & + & ++ & ++ & ++ & ++ & ++ & ++ & ++ & ++ & ++ & ++ & ++ \\
\hline $\mathrm{C} 4$ & + & + & + & + & ++ & ++ & ++ & ++ & ++ & ++ & ++ & ++ & ++ & ++ \\
\hline D1 & + & + & + & + & ++ & ++ & ++ & ++ & ++ & ++ & ++ & ++ & ++ & ++ \\
\hline D2 & + & + & + & + & ++ & ++ & ++ & ++ & ++ & ++ & ++ & ++ & ++ & ++ \\
\hline D3 & + & + & + & + & + & ++ & ++ & ++ & ++ & ++ & ++ & ++ & ++ & ++ \\
\hline D4 & + & + & + & + & + & ++ & ++ & ++ & ++ & ++ & ++ & ++ & ++ & ++ \\
\hline
\end{tabular}

Keterangan : (+) Respon gerak rendah, (++) Respon gerak normal

Peningkatan respon terhadap pakan berangsur normal pada hari ke-7 pasca uji tantang, namun perlakuan tanpa pemberian KDF (A) mengalami respon terhadap pakan yang sedang sampai akhir waktu penelitian. Hasil ini sesuai dengan riset Rosidah et al. (2018) dan Yustiati et al. (2019a, 2020a) yang menemukan bahwa perlakuan tanpa pemberian KDF memiliki respon pakan yang rendah, bahkan ikan uji tidak merespon pakan sampai hari ke3 setelah uji tantang dengan $A$. hydrophila.

Rendahnya respon pakan disebabkan ikan bawal air tawar mengalami stres, menurut Irianto (2005) stres merupakan suatu keadaan saat suatu hewan tidak mampu mengatur kondisi fisiologis yang normal karena berbagai faktor merugikan yang mempengaruhi kesehatannya. Salah satu reaksi ikan saat mengalami stres yaitu hilangnya nafsu makan. Selain itu, lamanya respon makan ikan untuk kembali normal dikarenakan tidak adanya KDF didalam saluran pencernaan yang dapat mengurangi jumlah bakteri A. hydrophila. Menurut Ng et al. (2009) KDF yang diberikan pada ikan nila merah dapat mengurangi total bakteri dalam usus per gram feses.

\section{b) Respon terhadap Kejutan}

Pengamatan selanjutnya yaitu respon terhadap kejutan dengan mengamati gerak pada ikan bawal air tawar pasca uji tantang dengan A. hydrophila. Cara untuk mengetahui respon terhadap kejutan adalah dengan mengetuk akuarium pada setiap perlakuan lalu diamati tingkah laku ikan uji. Pengamatan respon gerak ikan ini dapat dilihat dari respon terhadap kejutan dan cara berenang ikan. Menurut Olga (2012), dengan adanya infeksi A. hydrophila pada ikan akan menyebabkan kemampuan berenang akan menurun dan ikan akan sering berenang diatas permukaan air.

Berdasarkan hasil pengamatan pada Tabel 3, dapat dilihat bahwa semua perlakuan sudah mengalami respon yang rendah pasca uji tantang sejak hari ke-1 sampai hari ke-5. Hasil ini sesuai dengan penelitian Rosidah et al. (2018) yang melakukan uji tantang dengan menggunakan A. hydrophila pada ikan lele sangkuriang yang telah diberi ekstrak daun kelor menghasilkan tidak adanya respon terhadap kejutan sampai hari ke-3, sementara Yustiati et al. (2019a) melakukan uji tantang pada ikan lele sangkuriang yang diberi KDF dengan $A$. hydrophila menemukan bahwa seluruh perlakuan tidak merespon terhadap kejutan sampai hari ke-2. Penyebab ikan menjadi lambat terhadap respon kejutan adalah karena adanya suatu peradangan dan penyumbatan pembuluh darah atau suatu racun (Yuhana et al. 2008). Hal ini terbukti dengan adanya kerusakan pada pada tubuh bawal air tawar setelah diuji tantang oleh A. hydrophila (Gambar 4).

Perubahan tingkah laku renang yang terjadi pada penelitian ini adalah ikan menggerombol disekitar sumber oksigen (batu aerasi). Hal ini sejalan dengan penelitian Haryani et al. (2012), yaitu ikan yang diuji tantang oleh $A$. hydrophila mengalami stres, ikan berenang dengan posisi tubuh miring karena keseimbangan tubuh terganggu serta berenang menggerombol disekitar sumber oksigen (aerasi).

\section{SIMPULAN}

Berdasarkan hasil riset yang telah dilakukan, dapat disimpulkan bahwa penambahan $\mathrm{KDF} 0,3 \%$ pada pakan selama 35 hari memberikan hasil yang terbaik untuk ketahanan tubuh bawal air tawar dengan meningkatkan jumlah sel darah putih dari $6,8 \times 10^{4}$ $\mathrm{sel} / \mathrm{mm}^{3}$ menjadi $7,56 \times 10^{4} \mathrm{sel} / \mathrm{mm}^{3}$. Pasca uji tantang oleh A. hydrophila, perlakuan penambahan KDF 0,3\% memiliki nilai kelangsungan hidup tertinggi yaitu sebesar $55 \%$, jumlah total leukosit $12,6 \times 10^{4} \mathrm{sel} / \mathrm{mm}^{3}$, jumlah total eritrosit $1,89 \times 10^{6} \mathrm{sel} / \mathrm{mm}^{3}$, tidak menimbulkan gejala sirip geripis, serta memiliki respon pakan dan respon terhadap kejutan yang lebih baik daripada perlakuan lainnya.

\section{DAFTAR PUSTAKA}

Angka SL. (2001). Studi Karakterisasi dan Patologi Aeromonas hydrophila pada Ikan Lele Dumbo 
(Clarias gariepinus). Makalah Falsafah Sains, Institut Pertanian Bogor. 30 hlm.

Abu Elala NM \& Ragaa NM. (2015). Eubiotic effect of A Dietary Acidifier (Potassium Diformate) on The Health Status of Cultured Oreochromis niloticus. Journal of Advamced Research, 6, (4), 621-629.

Ali MF, Rashid MM, Rahman MM \& Haque MN. (2014). Pathogenicity of Aeromonas hydrophila in Silver Carp Hypophthalmichthys molitrix and its Control Trial. IOSR Journal of Agriculture and Veterinary Science (IOSRJAVS), 7, (6), 21-24.

Argenzio RA \& Eisemann J. (1996). Mechanisms of Acid Injury in Porcine Gastroesophageal Mucosa. American Journal of Veterinary Research, 57, (4), 564-573.

Arie U. (2009). Panen Bawal 40 Hari. Jakarta: PT. Penebar Swadaya.

Arreza J. (2017). Effect of Dietary Potassium Diformate (KDF) on Growth Perfomance of Juvenile Asian Seabass (Lates calcarifer) Reared Under Freshwater Conditions. Germany: ADDCON.

Austin B \& Austin DA. (1999). Bacterial Fish Pathogens, Disease of Farmed and Wild Fish. $3^{\text {rd }}$ edition, Goldming, Springer Praxis.

Austin B \& Austin DA. (2007). Bacterial Fish Patogens Diseases of Farmed and Wild Fish. Germany:Praxis Publising.

Bastiawan D, Alifudin M \& Dermawati TS. (1995). Perubahan Hematologi dan Jaringan Ikan Lele Dumbo (Clarias gariepinus) yang diinfeksi Cendawan Aphanomyces sp. Jurnal Riset Perikanan Indonesia, 4, (1), 106-115.

Cipriano RC \& Bullock GL. (2001). Furunculosis and other diseases caused by Aeromonas salmonicida. United States Geological Survey. Fish Disease Leaflet 66. 33 pp.

Da silva BCD, Vieira FDN, Mouriño JLP, Ferreira GS \& Seiffert WQ. (2013). Salts of organic acids selection by multiple characteristic for marine shrimp nutrition. Aquaculture, 384-387, 104110.

Effendie. (1997). Biologi Perikanan. Yayasan Pustaka Nusatama, Yogyakarta.

Haditomo AHC, Widanarni \& Lusiastuti AM. (2014). Perkembangan Aeromonas hydrophila pada Berbagai Media Kultur. Seminar Nasional keIII: Hasil-Hasil Penelitian Perikanan dan Kelautan. Semarang: Fakultas Perikanan dan Ilmu Kelautan Universitas Diponegoro. 357364.

Hardi EH, Sukenda, Harris E \& Lusiastuti AM. (2011). Karakteristik dan Patogenisitas Streptococcus agalactiae Tipe $\beta$-Hemolitik dan Non-Hemolitik pada Ikan Nila. Jurnal Veteriner, 12, (2), 152- 164.

Haryani A, Grandiosa R, Buwono ID \& Santika A. (2012). Uji Efektivitas Daun Pepaya (Carica papaya) untuk Pengobatan Infeksi Bakteri Aeromonas hydrophila pada Ikan Mas Koki
(Carassius auratus). Jurnal Perikanan dan Kelautan, 3, (3), 213-220.

Hasibuan AL. (2017). Status Kesehatan Ikan Bawal Air Tawar (Colossoma macropomum) di Keramba Sungai Kampar dan Kolam Desa Rumbio, Kabupaten Kampar. Laporan Hasil Penelitian. Riau: Universitas Riau.

Hastuti SD \& Karoror RJ. 2007. Pengaruh Pemberian Lps (Lipopolisacharida) Terhadap Aktifitas Fagositosis dan Jumlah Eritrosit Darah Ikan Nila (Oreocrhomis sp). Jurnal Protein, 15, (1), 1-9.

Irianto A. (2005). Patologi Ikan Teleostei. Yogyakarta: Gadjah Mada University Press.

Kabata Z. (1985). Parasites and Disease of Fish Cultured in the Tropics. London: Taylor and Francis.

Khasani I. (2006). Manajemen dan Pencegahan Penyakit pada Udang Galah. Media Akuakultur, 1, (2), 75-80.

Lantu, S. (2010). Osmoregulation in Aquatic Animals Osmoregulation in Aquatic Animals. Jurnal Perikanan dan Kelautan, 6, (1), 46-50.

Lückstädt C. (2008). The Use Of Acidifiers In fish Nutrition. CAB Reviews: Perspectives in Agriculture, Veterinary Science, Nutrition and Natural Resources, 3, (44), 1-8.

Mariyono \& Sundana A. (2002). Teknik Pencegahan Dan Pengobatan Penyakit Bercak Merah pada Ikan Air Tawar yang Disebabkan oleh Bakteri Aeromonas hydrophila. Buletin Teknik Pertanian, 7, (1), 23-29.

Moyle PB \& Cech JJ. (2004). Fishes. An Introduction to Ichthyology. 5th ed. USA: Prentice Hall Inc.

Mulia DS. (2007). Keefektifan Vaksin Aeromonas hydrophila Untuk Mengendalikan Penyakit MAS (Motile Aeromonas Septicemia) pada Gurami (Osphronemus gouramy Lac.). Jurnal Pembangunan Pedesaan, 7, (1), 43-52.

Muslim, Hotly MP \& Widjajanti H. (2009). Penggunaan Ekstrak Bawang Putih (Allium sativum) Untuk Mengobati Benih Ikan Patin Siam (Pangasius hypopthalmus) yang Diinfeksi Bakteri Aeromonas hydrophylla. Jurnal Akuakultur Indonesia, 8, (1), 91-100.

Nabib R \& Pasaribu FH. (1989). Patologi dan Penyakit Ikan. Bogor: PAU Bioteknologi, Institut Pertanian Bogor.

Ng WK, Koh CB, Sudesh K \& Zahrah AS. (2009). Effects of Dietary Organic Acids on Growth, Nutrient Digestibility and Gut Microflora of Red Hybrid Tilapia, Oreochromis sp., and Subsequent Survival During a Challenge Test with Streptococcus agalactiae. Aquaculture Research, 40, (13), 1490-1500.

Nzeako BC, Hasting TS \& Ellis AE. (1991). Cultural Conditions for Aeromonas hydrophila Affect The Production of Haemolysins with Different Host Specificities. Antonie van Leeuwenhoek, 60, 67-72.

Olga. (2012). Patogenesitas Bakteri Aeromonas hydrophila ASB01 pada Ikan Gabus 
(Ophicephalus striatus). Sain Akuatik, 14, (1), 33-39.

Price SA \& Wilson LM. (2006). Patophysiology. VI edition. Volume I. Philadelphia: EGC.

Rahmaningsih S. (2012). Pengaruh Ekstrak Sidawayah dengan Konsentrasi yang Berbeda untuk Mengatasi Infeksi Bakteri Aeromonas hydrophyla pada Ikan Nila (Oreochromis niloticus). AQUASAINS (Jurnal Ilmu Perikanan dan Sumberdaya Perairan). 1, (1), 1-7.

Ramli N, Heindl U \& Sunanto S. (2005). Effects of Potassium-Diformate on Growth Performance of Tilapia Challenged with Vibrio anguillarum. WAS Conference, May 9-13, 2005, Bali, Indonesia.

Rehulka J. (2002). Aeromonas Causes Severe Skin Lessions in Rainbow Trout (Oncorhynchus mykiss): Clinical Pathology, Haematology and Biochemistry. Acta Vet.BRNO, 71, 351-360.

Roberts RJ. (2001). Fish Pathology. 3th ed. Toronto: WB Saunders.

Rosidah, Buwono ID, Lili W, Suryadi IB \& Triandika AR. (2019a). Ketahanan Ikan Lele Sangkuriang (Clarias gariepinus Burchell 1822) terhadap Aeromonas hydrophila Pasca Pemberian Ekstrak Daun Kelor (Moringa oleifera L.) Melalui Pakan. Jurnal Iktiologi Indonesia, 19, (1), 97-113.

Rosidah, Nurruhwati I, Yunita MD \& Pratiwy FM. (2019b). Virulence Test of Aeromonas hydrophila Bacteria on Goldfish (Carassius auratus). International Journal of Fisheries and Aquatic Research, 4, (2), 15-20.

Rosidah, Lili W, Iskandar \& Afpriliansyah MR. (2018). Efektivitas Ekstrak Daun Kersen untuk Pengobatan Benih Ikan Nila yang Terinfeksi Bakteri Aeromonas hydrophila. Jurnal Akuatika Indonesia, 3, (1), 10-18.

Salasia SIO, Sulanjari D \& Ratnawati A. (2001). Studi Hematologi Ikan Air Tawar. Biologi, 2, (12), 710-723.

Setiawati M, Arry, Nuryati S, Mokoginta I, Suprayudi MA \& Manalu W. (2007). Pengaruh Suplementasi Fe-Anorganik Terhadap Gambaran Darah Kerapu Cromileptes altivelis Terinfeksi Bakteri Vibrio parahaemolyticus. Jurnal Biologi Indonesia, 4, (4), 203-215.

Sheng X F \& He L Y. (2006). Solubilization of Potassium Bearing Minerals by a Wild Type Strain of Bacillus Edaphicus and Its Mutants and Increased Potassium Uptake by Wheat. Can. J. Microbiol, 52, (1), 66-72.

Steel RGD \& Torrie JH. (1993). Prinsip dan Prosedur Statistika (diterjemahkan dari: Principles and Procedures of Statistic, penerjemah: B. Sumantri). Jakarta: PT Gramedia.

Sukandar AF, Mulyana \& Mumpuni FS. (2018). Gambaran Darah Ikan Nilem (Osteochilus hasselti CV) yang Terinfeksi Bakteri Aeromonas hydrophila. Jurnal Pertanian, 9, (2), 78-85
Sukenda L, Jamal, Wahjuningrum D \& Hasan A. (2008). Penggunaan Kitosan untuk Pencegahan Infeksi Aeromonas hydrophila Pada Ikan Lele Dumbo (Clarias sp.). Jurnal Akuakultur Indonesia, 7, (2), 159-169.

Sutisna A \& Luckstadt C. (2017). Innovative Solution for Sustainable Aquaculture. http://novindo .co.id/2017/01/17/hello-world/ (diakses pada 10 Agustus 2019).

Taufiq T, Firdus F \& Arisa II. 2016. Pertumbuhan Benih Ikan Bawal Air Tawar (Colossoma macropomum) Pada Pemberian Pakan Alami Yang Berbeda. Jurnal Ilmiah Mahasiswa Kelautan dan Perikanan Unsyiah, 1, (3), 355365.

Wahjuningrum D, Solikhah EH, Budiardi $\mathrm{T} \&$ Setiawati M. (2010). Infection Control of Aeromonas hydrophila in Catfish (Clarias sp.) Using Mixture of Meniran Phyllantus niruri and Garlic Allium sativum in Feed. Jurnal Akuakultur Indonesia, 9, (2), 93-103.

Wijayanti K. (2010). Pengaruh Pemberian Pakan Yang Berbeda Terhadap Sintasan dan Pertumbuhan Benih Ikan Palmas (Polypterus senegalus senegalus Cuvier, 1829). Skripsi. Universitas Indonesia. Depok.

Wiyanto DB. (2010). Uji Aktivitas Antibakteri Ekstrak Rumput Laut Kappaphycus alvarezii dan Euchema denticulatum terhadap Bakteri Aeromonas hydrophila dan Vibrio harveyii. Jurnal Kelautan, 3, (1), 1-17.

Yanto H, Hasan H \& Sunarto. (2015). Studi Hematologi untuk Diagnosa Penyakit Ikan Secara Dini di Sentra Produksi Budidaya Ikan Air tawar Sungai Kapuas Kota Pontianak. Jurnal Aquatika, 6, (2), 11-20.

Yuhana M. (2008). Pemanfaatan Ekstrak Bawang Putih Allium sativum Untuk Pencegahan dan Pengobatan Pada Ikan Patin Pangasionodon hypophthalmus yang Diinfeksi Aeromonas hydrophila. Jurnal Akuakultur Indonesia, 7, (1), 95-107..

Yustiati A, Aminah S, Walim L, Andriani Y dan Suryadi I B. (2019a). Effect of Using Potassium Diformate As a Feed Additive to Growth Rate and Feed Efficiency of Nirwana Tilapia (Oreochrmois niloticus). Global Scientific Journals, 7, (8), 739-750.

Yustiati A, Kundari DF, Suryana AAH \& Suryadi IBB. (2019b). Effectiveness of potassium diformate addition to Ffeed to Improve Immune System of Pangasius (Pangasianodon hypophthalmus) that Challenged by Aeromonas hydrophila. World Scientific News, 134, (2), 86-100.

Yustiati A, Nadiyah NA, Suryadi IB \& Rosidah. (2019c). Immune Performances of Sangkuriang Catfish (Clarias gariepinus) with Addition of Potassium Diformate on feed. World News Of Natural Sciences 25 : 113-129.

Yustiati A, Rusydagita S, Rosidah \& Suryadi IBB. (2020b). Potassium Diformate Feed Additive 
to Enhance the Performance of Immune System on Giant Gourami Fingerlings (Osphronemus goramy Lacepede, 1801). Asian Journal of Fisheries and Aquatic Research, 7 , (4), 22-29.

Yustiati A, Wahyuni RT, Rizal A \& Suryadi IBB. (2020a). Effectiveness of Potassium Diformate on Feed to Improve Immune Performance of Goldfish (Carassius auratus L.). Asian Journal of Fisheries and Aquatic Research, 7, (3), 2433.

Zhou Z, Liu Y, He S, Shi P, Gao X, Yao B \& Ringo E. (2009). Effect of Dietary Potassium Diformate (KDF) on Growth Performance, Feed Conversion and Intestinal Bacterial Community of Hybrid Tilapia (Oreochromis niloticus $\bigcirc$ x O. Aureus §ึ). Aquaculture, 291, 89-94. 